\title{
INSTITUTIONAL INVESTOR, ECONOMIC POLICY UNCERTAINTY, AND INNOVATION INVESTMENT: EVIDENCE FROM CHINA
}

\section{Zhenjiang Dou', Lei Wei', Jingyi Wang ${ }^{3}$}

\author{
1 Zhongnan University of Economics and Law, School of Finance, China, ORCID: 0000-0003-3542-4631, \\ doujiang1024@163.com; \\ 2 Zhongnan University of Economics and Law, School of Finance, China, ORCID: 0000-0002-2620-1658, \\ 18698432220@163.com (corresponding author); \\ 3 Hunan University of Humanities, Science and Technology, School of Business, China, ORCID: 0000-0002-6597-7862, \\ anmidi@sina.com.
}

\begin{abstract}
As a participator in corporate investment decision-making, the institutional investor is directly related to the corporate innovation investment. However, the economic policy uncertainty is aggravated by problems, such as economic slump and trade friction. Thus, institutional investors are not optimistic about the prospects of innovation investment. To explore the influence of institutional investors on corporate innovation investment from the perspective of economic policy uncertainty, using the 2010-2018 panel data in China and the fixed effect model, the influences of institutional investors on innovation investment and the moderating effects of the economic policy uncertainty were analyzed. Results show that institutional investors facilitate corporate innovation investment. Moreover, the increasing economic policy uncertainties repress the promoting effect of institutional investors on innovation investment. Furthermore, the institutional investors boost the corporate innovation investment by improving the internal control and relieving the financing constraints. For private companies, new and high-tech companies, the promoting effect of institutional investors on the corporate innovation investment is inhibited by the economic policy uncertainty to a small extent. For the listed companies located in areas with a high level of investor protection and intellectual property protection, the economic policy uncertainty has a minimal influence on the institutional investors and corporate innovation investment. The conclusions obtained from this study provide empirical evidence for giving full play to the role played by institutional investors in corporate innovative development. The conclusions also reveal, from the macroscopic level, that the consistency and stability of governmental economic policies have important effects on corporate development.
\end{abstract}

Keywords: Economic policy uncertainty, institutional investor, innovation investment.

JEL Classification: D21, G34, M21.

APA Style Citation: Dou, Z.-J., Wei, L., \& Wang, J.-Y. (2021). Institutional Investor, Economic Policy Uncertainty, and Innovation Investment: Evidence from China. E\&M Economics and Management, 24(1), 4-20. https://doi.org/10.15240/tul/001/2021-1-001

\section{Introduction}

Innovation-driven economic development is a global trend. Specifically, in the SinoAmerican trade war, the events, such as the suppression of Huawei $5 G$, knock the alarm bell of independent research and development (R\&D) in all countries. Hence, the entire society is aware of the strategic significance of corporate innovation and key technologies to the companies and the entire country. Compared with traditional investments, such as fixed assets investment, the innovation investment is featured by large capital demand, long recycling period, high risk, and others. The interruption of the capital supply chain will generate high adjustment costs and sunk costs (Ju et al., 2013; Gu et al., 2019). As important enterprise managers, institutional 
investors have become an important force that cannot be ignored in the current capital market. The American financial market is the most developed market across the globe, and the institutional investors account for over $80 \%$ of the American stock market. Up to the end of 2018 , the total market value held by nine types of professional institutional investments, such as foundation and insurance, occupied $12.6 \%$ of the total value of Shanghai and Shenzhen stock markets in China. Therefore, the corporate core competitiveness can be enhanced. Moreover, their long-term development can be maintained, considerably, by giving full play to the promoting effect of institutional investors on the corporate innovation investment.

With the continuous improvement of China's capital market, institutional investors have an ignorable influence in the corporate operation process by exerting the functions of improving the corporate information quality (Bushee \& Goodman, 2007; Kong et al., 2019) and maintaining the market stability (An \& Zhang, 2013; Callen \& Fang, 2013). These functions, if well exerted, can elevate the corporative governance level ( $\mathrm{Yi}$ et al., 2010; Bushee et al., 2014; Jahnke, 2019) and corporate value (Chemmanur et al., 2009). In addition, such functions can improve corporate performance (Ferreira \& Matos, 2008; Li \& Han, 2013; Wondirad, 2020), thus further facilitating the companies to proactively fulfill their social responsibilities (Amel-Zadeh \& George, 2018; Nofsingera et al., 2019; Agudelo et al., 2019). Investor protection provides a guarantee for the institutional investors to improve the corporate internal governance (La Porta et al., 2000), allow full play to their operating management function, and greatly alleviate the financing constraints (Whited \& Wu, 2006; Fan, 2018). However, faced with the pressure of economic downturn, the Chinese government has promoted a series of economic policies to support the economic transformation and upgrading and provides an impetus for sustainable economic development. Nevertheless, the frequent formulation and adjustment of financial and monetary policies will aggravate the uncertainty of economic policies. According to Baker's statistical data, China's economic policy uncertainty index has been rising since 2012 , which is related to a series of supply-side structural reform policies promulgated by the Chinese government in recent years. In the context of ever-aggravated economic policy uncertainty in China, few scholars have paid attention to the moderating effect of economic policy uncertainty on institutional investors and innovation investment. The institutional investors share common interests with the company as its stakeholders. Relative to individual investors, institutional investors have more rational investment concepts and more sensitive to the change of economic policies. The corporate decisions made by the institutional investors are influenced, at all times, by the high risk of innovation investment and uncertainty of the external economic environment, including corporate development.

Hence, the 2010-2018 data of A-sharelisted companies in Shanghai and Shenzhen stock markets were selected. From the perspective of institutional investors, the economic policy uncertainty and institutional investors were combined with innovation investment to discuss the following questions: (1) Do institutional investors facilitate the corporate innovation investment? (2) How does the uncertainty of external macroeconomic policies influence institutional investors and innovation investment? (3) What is the action mechanism of institutional investors on the innovation investment?

First, from the influence of institutional investors on the innovation investment, the effect of institutional investors on corporate innovation investment was revealed. Second, the moderating effect of economic policy uncertainty on institutional investors and innovation investment was analyzed, and the impact of economic policy uncertainty on institutional investors and innovative investment was explored. Third, the influence mechanism of institutional investors on corporate innovation investment was discussed. Finally, the influence of institutional investors on the corporate innovation investment was deeply probed by analyzing company differences. In comparison with those of the existing literature, the marginal contributions of this study were manifested by the following aspects: the external macroenvironment is the foundation and precondition for enterprise decision-making, and the investment decisions of micro-enterprises will be influenced by the macroeconomic policies. The discussion about institutional investors stays at the micro-level in most of the present literature, whereas the micro-level has been involved 
limitedly. This study exerted efforts to extend the research category of previous scholars and introduced the macroscopic economic policy uncertainty into the research on the relationship between institutional investors and innovation investment. The study also explored its modulating effect on institutional investors and innovation investment. Although extending the research literature regarding institutional investors, this research provides a macroscopic explanation basis for the existing literature from the level of micro-company.

The remainder of this study is arranged as follows: Section 1 sorts out the related literature involving the relationship between institutional investors and innovation investment and the regulatory role played by economic policy uncertainty. The study also proposes the research hypotheses. Then, Section 2 introduces the research data and design, defines the related variables, and constructs empirical models. Section 3 analyzes the empirical result and displays the effect, influence mechanism, and heterogeneous influence of institutional investors on the innovation investment. This section also expounds on the moderating effect of economic policy uncertainty and further implements the robustness test. Next, Section 4 further discusses the results and explains the possible reasons for the empirical results. Finally, Section 5 concludes the main research.

\section{Literature Review and Research Hypotheses}

\subsection{Influence of Institutional Investors on Innovation Investment}

Since 2001, China's financial regulatory agencies have proactively developed institutional investors. Therefore, the institutional investors, which are represented by securities investment funds, have achieved considerable progress. Moreover, they played significant roles in guiding the investments, stabilizing the market, and others. They have exerted increasingly significant influences and functions in China's capital market through more than 10 years of development. Their influence on the corporate innovation investment is mainly manifested by two aspects, namely, corporate governance and financing constraint.

The institutional investors influence the corporate innovation investment by exerting the effect of external corporate governance.
They participate in the corporate management, standardize the corporate operation, propose governance problems and suggestions (Hartzell \& Starks, 2003; McCahery et al., 2016), and conduct field investigations on the invested companies whenever possible (Filatotchev et al., 2019). Moreover, they have significant influences on the aspects of the formulation of personnel change plans, long-term development strategies, and others. Meanwhile, innovation investment is an important guarantee for the company to win market share and is of great significance to the company's survival and development. The institutional investors evade the short-sighted behaviors of the management level, rationally analyze the market prospects, and strengthen the innovation investment by elevating its proportion through direct participation and proposal submission (Chen et al., 2007). Compared with retail investors, the institutional ones have stronger professional knowledge and more advanced governance concepts. They also understand and master the importance of innovation investment to long-term corporate value and externally impose pressure on corporate governance status by playing the role of "signal" ( $\mathrm{Li} \& \mathrm{Li}$, 2008; Schmalz, 2018). In addition, institutional investors supervise the management layer more effectively, reduce their self-interest behaviors (Lu et al., 2012), and further boost the implementation of innovation investment decisions. The institutional investors, which press close to the corporate management layer, are also usually considered the traders with information superiority in the market (Bushee \& Goodman, 2007). Thus, acquiring "soft information" is easier for them, thereby reducing the information asymmetry. Connelly et al. (2010) pointed out that if the proportion of shares held by the institutional investors is high, then the advantage in acquiring the information is highly evident, and the governance degree disclosed in the corporate information is also high. They further noted that the governance effect would be more apparent, and the positive governance effect weakens the agency problem generated by the goal inconsistency between the management layer and shareholders. As the direct stakeholders (Borochin \& Yang, 2017; Liang, 2018), the institutional investors proactively promote the corporate implementation of innovation investment decisions and guarantee and ensure 
the investment benefits of the companies to increase their own benefits. The innovation investment requires long-term corporate support in the aspects, such as information, talent, and technology. The institutional investors collect the investment information (Dierksmeier \& Seele, 2020), recruit investment professionals, participate in the independent innovation decision-making of the invested companies (Gillan \& Starks, 2003), and ensure the value-added effect of the investment projects. With the increasing shareholding ratio of institutional investors, the scope of their corporate governance will be broader, and the depth of governance will be greater. Therefore, they will have more positive motivations to participate in corporate governance to facilitate corporate innovation activities and support corporate innovation investment.

The institutional investors act on the corporate innovation investment by influencing the financing constraints faced by the company. High risk, high failure rate, unpredictability, and great time consumption are the outstanding features of innovation investment, and the long-term maintenance can be ensured only with substantial capital (Xie \& Fang, 2011). Hence, innovation investment is more easily influenced by financing constraints. For the fund suppliers, the institutional investors have objective cognition of the corporate value. As rational investors relative to individual investors, the institutional investors mostly regard the corporate value as a basis for investment decision-making while not being influenced by the information beyond the value. They are capable of understanding and mastering the information, such as the importance of corporate innovation investment to long-term corporate value. Thus, the shortsighted decisions faced by the corporate management layer are reduced, and they are more prone to the benefits brought by the innovation investment (Fan, 2018). The institutional investors can promote the corporate innovation investment and remit their financing constraints. The listed companies in China have a highly centralized ownership structure, which gives rise to the serious "insider control" problem. As the corporate agency problem becomes more severe, the share premium required by the investors will be higher, and the financing constraints will become more serious. The institutional investors can relieve the agency problem, reduce the opportunistic behaviors of corporate insiders, such as fund embezzlement, and remit the corporate financing constraints (Aggarwal et al., 2011). The innovation process has a high degree of information asymmetry, and the innovation outputs are generally intangible, with a value difficult to evaluate. Hence, obtaining the bank credits with innovation outputs as the mortgages is hard, the financing cost of innovation activities is high (Barber \& Odean, 2008; Brown \& Petersen, 2011), and the financing constraints can significantly repress the corporate R\&D input (Boone \& White, 2015). The institutional investors transmit the positive signal of the invested company and shape a good image for it through their investment behaviors. They are able to approach the corporate management layer and acquire "soft information", which cannot be acquired by ordinary investors. Moreover, institutional investors transmit information related to corporate innovation activities to the outside world through information disclosure. This process can reduce the information asymmetry of corporate innovation activities, help the company to attract the attention of external fund suppliers, and increase the investment possibility. Therefore, institutional investors remit corporate financing constraints and facilitate their innovation activities to a certain extent.

To sum up, as an effective external governance mechanism, the institutional investors can bring down the principal-agent problem and relieve the information asymmetry. They can also alleviate corporate financing constraints by improving corporate internal governance. On this basis, the following hypotheses are proposed:

H1: Institutional investors drive corporate innovation investment.

H1a: Institutional investors improve the corporate innovation investment through their external corporate governance effect.

H1b: Institutional investors facilitate the corporate innovation investment by relieving the financing constraints.

\subsection{Moderating Effect of Economic Policy Uncertainty}

The economic policy uncertainty is generated when the economic subjects fail to accurately 
predict whether, when, and how the government will change the current economic policies (Gulen \& Ion, 2015). Such uncertainty also occurs when the formulation, enforcement, and implementation effect of economic policies are unclear (Baker et al., 2016; Rao et al., 2017). In the present economic downturn, various problems are outstanding, such as weak market demand, underinvestment, and excess production capacity. Hence, the government frequently adjusts the economic policies to stimulate economic development to adapt to the new normalcy of China's economic development. This adjustment will certainly increase the uncertainty of economic policies (Rao et al., 2017) and further influence the corporate innovation investment decisionmaking. The frequent adjustment of economic policies from the perspective of the principalagent problem has greatly aggravated the information asymmetry. Considering self-interest motivation, the management supervisors are more prudent in decisionmaking to evade the risks, which aggravates the decision-making difficulty, and reduce the investment level (Panousi \& Papanikolaou, 2012). Therefore, when the uncertainties of economic policies are increased, the principalagent and information asymmetry problems in the corporate R\&D process will be aggravated. Moreover, innovation investment requires sustainable input and concern. Furthermore, given the long period and large fund demand, the institutional investors will cancel the innovation investments with high uncertainties out of consideration of their own interests. Thus, forming unified opinions and planning inside the company are difficult because of the increasing uncertainties of economic policies, thereby discouraging the enthusiasm of institutional investors for innovation activities and reducing the innovation investment.

Second, the frequent formulation of macroeconomic policies based on the judgment of corporate risk will greatly drive the fluctuations of the stock price. In addition, the business environment faced by the company will become more complicated, and thus, the external risks will be increased (Pástor \& Veronesi, 2013; Hoque et al., 2019). Under unstable or uncertain external macro-environment, the company will face an increasingly severe survival environment. Hence, the company will adjust the investment and operation strategies, expecting to offset the ever-increasing external risks by reducing its internal risks to avoid the superposition of internal and external risks. The institutional investors play important roles in the corporate operation and management and positively drive the decision-making, which disperses and offsets the corporate risks. They participate in corporate investment decisionmaking through investigation, voting, and others. The institutional investors also evade the corporate risks under negative external situations, curtail the innovation investments (Bhattacharya et al., 2017; Lu et al., 2019c), and thus inhibit the corporate innovation investment.

In the end, from the theory of real option, if the corporate investment is regarded as a call option, then the uncertainty will increase the risk premium and option value under irreversible investment. The company will also postpone the current investment until the economic policy uncertainty tends to be steady (Bloom et al., 2007; Pan et al., 2020). Starting from the theory of real option, the institutional investors will neglect the importance of innovation investment and postpone the current innovation investment decision-making during the corporate operation process due to the economic policy uncertainty. With the economic policy uncertainty, the institutional investors will attach importance to the increase of the current value, so the innovation investments are reduced. Given this, the following hypothesis is put forward:

H2: As the economic policy uncertainty increases, the promoting effect of institutional investors on the innovation investment decreases.

\section{Methodology}

\subsection{Data Sources and Sample Selection}

In view of the data disclosure regarding the R\&D input of listed companies, the A-sharelisted companies in Shanghai and Shenzhen stock markets in 2010-2018 were selected as the research samples, which were screened and processed as follows: (1) The financial companies were excluded; (2) The ST and ST*-type-listed companies were excluded; (3) Companies with financial data missing were excluded; (4) The company-year samples undergoing insolvency were excluded; (5) The winsorization was implemented for all continuous variables in the model to reduce the 
influence of extreme outliers. A total of 9,072 company-year observed values of 1,008 listed companies were finally obtained. The economic policy uncertainty data were collected from the China economic policy uncertainty index compiled by Baker et al. (2018) through the keyword search in South China Morning Post. The other data, such as annual shareholding information of institutional investors, basic information of listed companies, transaction data, and financial data, are all derived from the Wind database.

\subsection{Modeling}

To verify the previously proposed hypotheses, the 2008-2018 data of listed companies in China were utilized to construct the following models:

$$
\begin{aligned}
& R D_{i, t}=\beta_{0}+\beta_{1} \text { Institution }_{i, t}+\sum \text { Control }_{i, t}+ \\
& +\sum \text { Year }+\sum \text { Industry }^{+} \varepsilon_{i, t} \\
& R D_{i, t}=\beta_{0}+\beta_{1} \text { Institution }_{i, t}+\beta_{2} \text { EPU }_{i, t}+ \\
& +\beta_{3} \text { Institution }_{i, t} \times \text { EPU }_{i, t}+\sum \text { Control }_{i, t}+ \\
& +\sum \text { Year }+\sum \text { Industry }^{+} \varepsilon_{i, t}
\end{aligned}
$$

Model (1) is used to investigate the influence of institutional investors on the innovation investment, whereas model (2) aims to explore the influence of economic policy uncertainty on institutional investors and innovation investment. Model (2) focuses on the interaction coefficient between economic policy uncertainty and institutional investors.

$$
\begin{aligned}
& \text { Con }_{i, t}=\delta_{0}+\delta_{1} \text { Institution }_{i, t}+\sum \text { Control }_{i, t}+ \\
& +\sum \text { Year }+\sum \text { Industry }^{+} \varepsilon_{i, t}
\end{aligned}
$$

Models (1), (3), and (4) are used to verify the mediating effect of corporate governance (Con), whereas models (1), (5), and (6) are combined to verify the mediating effect of financing constraints (SA).

\subsection{Variables}

\section{Explained Variable}

Innovation investment: The current indexes used to measure the innovation input include the following: the proportion of R\&D expenditure in total assets, main business income, and total market value of the company. As the stock markets in China are not complete, the total market values of companies are of great uncertainty and variability. Moreover, the proportion of total assets, main business income, and others are greatly influenced by external factors, such as market situation. Then, the logarithm of company R\&D input is taken as the proxy variable, which is used to measure the innovation investment (RD) with reference to Kong et al. (2019).

\section{Explanatory Variable}

Institutional investors: The institutional investors participate in corporate management mainly by holding their shares. Following Liang (2018), the shareholding ratio of institutional investors is used as the proxy variable of institutional investors, namely, the proportion of shares held by institutional investors in the number of a company's circulating shares at the end of the year (Institution). In the meantime, several institutions are involved in the company's shareholding. The degree to which the company is supervised by the institutions and the degree of its information disclosure may also be elevated. Therefore, according to Gao et al. (2020), the robustness test was conducted by taking the number of institutional investors holding shares of the company each year as a proxy variable.

\section{Moderator Variable}

Economic policy uncertainty: The economic policy uncertainty was measured using the economic policy uncertainty index (EPU) released jointly by Stanford University and University of Chicago. Based on the test analysis by taking South China Morning Post, founded in 1903, with the maximum circulation in Hong Kong, as the sample, Baker et al. (2016) identified the monthly published reports containing keywords, such as "China", "economy", "uncertainty", and "policy" in this newspaper. They calculated the proportion of these reports in the total number of reports in this month to determine the monthly data of China's economic policy uncertainty. Then, the 
arithmetic mean value of the monthly economic policy uncertainty index was solved to acquire the annual data of economic policy uncertainty. In consideration of problems similar to the regression coefficient, the arithmetic mean value was divided by 100 (Rao et al., 2017).

\section{Mediator Variables}

The corporate governance (Con) and financing constraint (SA) were selected as the mediator variables, which were measured in the following ways: (1) the corporate governance (Con) was standardly measured using the internal control index of listed companies released by $\mathrm{Xu}$ et al. (2019) in DIB internal control and risk management database. (2) The financing constraint (SA) was measured after the SA index was established with reference to Hadlock and Pierce (2010) through the following model:

$$
\begin{aligned}
& S A=-0.737 \times \text { Size }+0.043 \times \text { Size }^{2}- \\
& -0.04 \times \text { Age },
\end{aligned}
$$

where Size is the natural logarithm of total circulating market value, and Age is the time length of the transaction after listing. As the SA value increase, the financing constraint of listed companies will also increase.

Control variables: According to Liang (2018), company size (Size: Logarithm of yearend number of company employees); liabilityasset ratio (LEV: Total liabilities/total assets); profitability (namely, return on equity, ROE: Net profit/gross revenue); growth ability (Growth: Growth rate of business revenue/100); duration of listing (AGE: Logarithm taken from number of years of listing +2 ); share ratio of the largest shareholder (FH: Number of shares hold by the largest shareholder/total number of shares); cash holding (Cash: Net operational cash flow/gross revenue); number of independent directors (IND: Year-end number of company's independent directors); number of directors (DIRECTOR: Year-end number of company's directors); duality (DUAL: If a person takes the posts of president and general manager simultaneously, the variable value is 1 , or otherwise it is 0 ); international four major audit firms (SIDA: If the audit firm is among the international four major audit firms, the variable value is 1 , or otherwise it is 0 ) were selected as the control variables. Then, year (Year) and industry (Industry) were controlled.

\section{Result Analysis}

\subsection{Basic Regression Analysis}

First, the regression analysis is conducted using model (1), and the fixed effects of year and industry are controlled using the fixed effect regression model. The standard error of regression was corrected through the company clustering effect. Tab. 1 shows the standard regression results regarding the influence of institutional investors on corporate innovation investment. In column (1), the time and industry effects are not controlled, but they are controlled in column (3). The obtained regression results indicate that the shareholding ratio of institutional investors is significantly positive at the $1 \%$ level. This result also certifies that institutional investors have a promoting effect on corporate innovation investment. In other words, with the increasing shareholding ratio of the institutional investors, the company expenditure in innovation investment is also increased.

From the previous part, the institutional investors facilitate innovation investment. If $\mathrm{H} 2$ holds true, then the interaction coefficient should be significantly negative. The time and industry effects are not controlled in column (2) of Tab. 1 but controlled in column (4). According to the regression results, the interaction term between the shareholding ratio of institutional investors and the economic policy uncertainty index is significantly negative at the $1 \%$ level. This finding means that the economic policy uncertainty represses the promoting effect of institutional investors on the innovation investment. Moreover, the supporting degree of institutional investors on the innovation investment is reduced. When the economic policy uncertainty is elevated, the promoting effect of institutional investors on the innovation investment will be weakened, so $\mathrm{H} 2$ is verified.

\subsection{Influence Mechanism Analysis}

The classical three-step mediating effects test method was used to verify the mediating effects of financing constraint (SA) and corporate governance (Con). With reference to Wen et al. (2006), the test was carried out according to the following steps: regression of model (1) and verification of models (3) and (4) on the precondition that is significant. 
Tab. 1:

Institutional investors and innovation investment

\begin{tabular}{|c|c|c|c|c|}
\hline Variable & (1) & (2) & (3) & (4) \\
\hline Institution & $\begin{array}{c}0.075^{\star * *} \\
(0.054)\end{array}$ & $\begin{array}{c}0.224^{* * *} \\
(0.068)\end{array}$ & $\begin{array}{c}0.174^{* * *} \\
(0.049)\end{array}$ & $\begin{array}{c}0.280^{* * *} \\
(0.065)\end{array}$ \\
\hline Institution $\times E P U$ & & $\begin{array}{c}-0.047^{\star *} \\
(0.019)\end{array}$ & & $\begin{array}{c}-0.046^{\star \star *} \\
(0.018)\end{array}$ \\
\hline EPU & & $\begin{array}{c}0.142^{* * *} \\
(0.010)\end{array}$ & & $\begin{array}{c}0.223^{* * *} \\
(0.012)\end{array}$ \\
\hline Size & $\begin{array}{c}0.812^{* * *} \\
(0.035) \\
\end{array}$ & $\begin{array}{c}0.787^{* * *} \\
(0.035)\end{array}$ & $\begin{array}{l}0.744^{* * *} \\
(0.031) \\
\end{array}$ & $\begin{array}{c}0.745^{\star * *} \\
(0.031)\end{array}$ \\
\hline GROWTH & $\begin{array}{c}0.001 \\
(0.004)\end{array}$ & $\begin{array}{l}-0.001 \\
(0.004)\end{array}$ & $\begin{array}{l}0.030^{*} \\
(0.017)\end{array}$ & $\begin{array}{l}0.029^{*} \\
(0.017)\end{array}$ \\
\hline ROE & $\begin{array}{c}0.000 \\
(0.000)\end{array}$ & $\begin{array}{c}0.000 \\
(0.000)\end{array}$ & $\begin{array}{c}0.006^{* * *} \\
(0.001)\end{array}$ & $\begin{array}{c}0.006^{* * *} \\
(0.001)\end{array}$ \\
\hline LEV & $\begin{array}{c}-0.002^{* * *} \\
(0.001)\end{array}$ & $\begin{array}{c}-0.002^{* *} \\
(0.001)\end{array}$ & $\begin{array}{c}0.001 \\
(0.001)\end{array}$ & $\begin{array}{c}0.001 \\
(0.001)\end{array}$ \\
\hline $\mathrm{FH}$ & $\begin{array}{c}-0.071^{* * *} \\
(0.018)\end{array}$ & $\begin{array}{c}-0.045^{\star * *} \\
(0.016)\end{array}$ & $\begin{array}{l}-0.013 \\
(0.023)\end{array}$ & $\begin{array}{l}-0.009 \\
(0.023)\end{array}$ \\
\hline IND & $\begin{array}{c}0.028 \\
(0.029)\end{array}$ & $\begin{array}{c}0.031 \\
(0.028)\end{array}$ & $\begin{array}{c}0.044 \\
(0.028)\end{array}$ & $\begin{array}{c}0.044 \\
(0.028)\end{array}$ \\
\hline DIRECTOR & $\begin{array}{l}-0.013 \\
(0.011)\end{array}$ & $\begin{array}{l}-0.009 \\
(0.011)\end{array}$ & $\begin{array}{c}0.001 \\
(0.010)\end{array}$ & $\begin{array}{c}0.001 \\
(0.010)\end{array}$ \\
\hline $\mathrm{CASH}$ & $\begin{array}{l}0.001^{* *} \\
(0.000)\end{array}$ & $\begin{array}{l}0.001^{*} \\
(0.000)\end{array}$ & $\begin{array}{l}-0.001 \\
(0.001)\end{array}$ & $\begin{array}{l}-0.001 \\
(0.001)\end{array}$ \\
\hline AGE & $\begin{array}{l}-0.003 \\
(0.002)\end{array}$ & $\begin{array}{c}-0.012^{* * *} \\
(0.003)\end{array}$ & $\begin{array}{c}-0.422^{* * *} \\
(0.064)\end{array}$ & $\begin{array}{c}-0.423^{* * *} \\
(0.064)\end{array}$ \\
\hline DUAL & $\begin{array}{c}0.067^{* * *} \\
(0.024)\end{array}$ & $\begin{array}{l}0.051^{* *} \\
(0.024)\end{array}$ & $\begin{array}{c}0.026 \\
(0.021)\end{array}$ & $\begin{array}{c}0.026 \\
(0.021)\end{array}$ \\
\hline SIDA & $\begin{array}{c}0.287^{* * *} \\
(0.067)\end{array}$ & $\begin{array}{c}0.296^{\star \star \star} \\
(0.068)\end{array}$ & $\begin{array}{c}0.296^{* * *} \\
(0.056)\end{array}$ & $\begin{array}{c}0.297^{* * *} \\
(0.056)\end{array}$ \\
\hline Constant & $\begin{array}{c}5.085^{\star * *} \\
(0.117)\end{array}$ & $\begin{array}{c}4.830^{* * *} \\
(0.118)\end{array}$ & $\begin{array}{c}4.392^{* * *} \\
(0.188)\end{array}$ & $\begin{array}{c}4.142^{* * *} \\
(0.189)\end{array}$ \\
\hline Year & No & No & Yes & Yes \\
\hline Industry & No & No & Yes & Yes \\
\hline Observations & 9,072 & 9,072 & 9,072 & 9,072 \\
\hline R-squared & 0.375 & 0.418 & 0.513 & 0.513 \\
\hline
\end{tabular}

Source: own

Note: ${ }^{*},{ }^{* *}$, and ${ }^{* * *}$ indicate statistical significance at the $10 \%, 5 \%$, and $1 \%$ levels, respectively; t-values reported in parentheses.

If and are significant, then the institutional investors influence the innovation investment partially by reducing the financing constraints. If is significant (insignificant), then the agency problem exerts a partial (complete) mediating effect. On the contrary, if at least one between and is insignificant, then whether the mediating effect is significant should be judged through the Sobel test. The principles of models (5) and (6) are identical with those of models (3) and (4).

The test process is the same as the previous part. The coefficient of Institution in column (3) of Tab. 2 is significantly negative, indicating that the institutional investors relieve the financing 


\section{Tab. 2: Regression results of influence mechanism of institutional investors}

\begin{tabular}{|c|c|c|c|c|}
\hline Variable & $\begin{array}{l}\text { Con } \\
\text { (1) }\end{array}$ & $\begin{array}{l}\text { RD } \\
\text { (2) }\end{array}$ & $\begin{array}{l}\text { SA } \\
\text { (3) }\end{array}$ & $\begin{array}{l}\text { RD } \\
\text { (4) }\end{array}$ \\
\hline Institution & $\begin{array}{c}0.023^{* * *} \\
(0.004)\end{array}$ & $\begin{array}{l}0.090^{*} \\
(0.050)\end{array}$ & $\begin{array}{c}-0.019^{*} \\
(0.011)\end{array}$ & $\begin{array}{l}0.101^{* *} \\
(0.051)\end{array}$ \\
\hline SA & & & & $\begin{array}{c}-0.309^{\star *} \\
(0.128) \\
\end{array}$ \\
\hline Con & & $\begin{array}{c}0.736^{* * *} \\
(0.128)\end{array}$ & & \\
\hline Controls variables & Yes & Yes & Yes & Yes \\
\hline Constant & $\begin{array}{c}0.570^{* * *} \\
(0.012)\end{array}$ & $\begin{array}{c}4.360^{* * *} \\
(0.199) \\
\end{array}$ & $\begin{array}{c}2.622^{* * *} \\
(0.034)\end{array}$ & $\begin{array}{c}5.591^{* * *} \\
(0.371) \\
\end{array}$ \\
\hline Year & Yes & Yes & Yes & Yes \\
\hline Industry & Yes & Yes & Yes & Yes \\
\hline Observations & 6,181 & 6,181 & 6,181 & 6,181 \\
\hline R-squared & 0.210 & 0.557 & 0.855 & 0.555 \\
\hline
\end{tabular}

Source: own

Note: ${ }^{*},{ }^{* *}$, and ${ }^{* * *}$ indicate statistical significance at the $10 \%, 5 \%$, and $1 \%$ levels, respectively; t-values reported in parentheses.

constraints. Moreover, the coefficient of SA in column (4) is significantly positive. This result means that institutional investors influence the corporate innovation investment by influencing the financing constraints. The coefficient of Institution in column (4) is significantly positive. This result indicates that, according to the test procedures of Wen et al. (2006), reducing the financing constraints is a partial mediator between institutional investors and corporate innovation investment. Hence, $H 1 b$ is verified.

\subsection{Endogeneity Analysis}

The following robustness test was implemented to further verify the reliability of regression results and make the conclusions more robust.

In consideration of the possible reversal cause-effect problem between institutional investors and corporate innovation investment, namely, the institutional investors will probably hold more shares in the companies with satisfying innovation investment, the instrumental variable method was used in this study to solve the sample endogeneity problem. The number of institutional investors holding shares in the invested company was used for the regression of instrumental variables with reference to Gao et al. (2020). From the regression results in Tab. 3, the number of institutional investors in the invested company (Number) in column 1 is significantly positive at the $1 \%$ level. Moreover, the interaction coefficient between Number and EPU in column 2 is significantly negative at the $1 \%$ level, so the research conclusion still holds true.

\subsection{Robustness Test}

Different from the simple arithmetic mean method for the monthly data of economic policy uncertainty, the annual EPU was calculated using the geometric mean method. With reference to the processing method adopted by Pástor and Veronesi (2013), the geometric mean of the 12-month data in each year was taken to obtain the annual EPU data, which was then used as the EPU index of this year, specifically shown in Formula (8):

$$
E P U S^{y e a r}=\sqrt[12]{E P U_{1}^{\text {month }} E P U_{2}^{\text {month } \cdots \cdots E P U_{12}{ }^{\text {month }}}}
$$

where EPUS $S^{\text {year }}$ is the annual economic policy uncertainty index, $E P U_{1}^{\text {month }}, E P U_{2}^{\text {month }}, \ldots$, $E P U_{12}$ month represent the economic policy uncertainty indexes in 12 months within one year, respectively, and column (1) of Tab. 4 shows the regression results. The influence of economic policy uncertainty on the institutional investors and innovation investment still appears significant, and the main research conclusion holds unchanged. 
Tab. 3: Regression results of instrumental variables

\begin{tabular}{l|c|c}
\multicolumn{1}{c|}{ Variable } & $\mathbf{( 1 )}$ & $\mathbf{( 2 )}$ \\
\hline Number & $0.002^{* * *}$ & $\begin{array}{c}0.004^{* * *} \\
(0.000)\end{array}$ \\
\hline Number×EPU & & $\begin{array}{c}-0.001^{* * *} \\
(0.000)\end{array}$ \\
\hline EPU & & $\begin{array}{c}0.208^{* * *} \\
(0.009)\end{array}$ \\
\hline Controls variables & & Yes \\
\hline Constant & Yes & $4.566^{* * *}$ \\
\hline Year & $4.757^{* * *}$ & $(0.186)$ \\
\hline Industry & $(0.187)$ & Yes \\
\hline Observations & Yes & Yes \\
\hline R-squared & Yes & 9,072 \\
\hline
\end{tabular}

Source: own

Note: ${ }^{*},{ }^{* *}$, and ${ }^{* * *}$ indicate statistical significance at the $10 \%, 5 \%$, and $1 \%$ levels, respectively; t-values reported in parentheses.

The main problem faced in the research on economic policy uncertainty is the missing variable problem. The influences of economic policy uncertainty as discovered in this research may include the influences of factors, such as macroeconomic uncertainty. In the previous regression analysis, the corporate internal factors are controlled, without the consideration of the influence of macroeconomic uncertainty, which may exist. In view of the influence of macroeconomic uncertainty, the macroeconomic leading indicator (MLI), consumer confidence index $(\mathrm{CCl})$, and entrepreneur confidence index $(\mathrm{ECI})$ were added into the regression analysis, similar to McCahery et al. (2016) to measure macroeconomic uncertainty. Column (2) of Tab. 4 presents the results consistent with the principal regression, thereby verifying the robustness of the research conclusions.

\subsection{Heterogeneity Analysis}

Under the special market system environment in China, the nature of property rights will have a great influence on management behaviors. According to the nature of property rights of listed companies, the full samples were divided into state-owned and private company groups, followed by the test group using model (1). The regression results in columns (1) and (2) of Tab. 5 show that the interaction coefficient between institutional investors and economic policy uncertainty is significantly negative in the state-owned companies but insignificantly positive in the private companies. This result demonstrates that the institutional investors in the state-owned companies weaken their innovation investment due to the economic policy uncertainty, which further reduces their promoting effect on the innovation investment. However, among private companies, the influence of economic policy uncertainty on the innovation investment of institutional investors is insignificant. Based on the above results, the economic policy uncertainty exerts evidently different effects on the relationship between institutional investors and corporate innovation investment under different natures of property rights. Furthermore, the economic policy uncertainty restricts the effect exerted by the institutional investors in the state-owned companies.

The densities of technological factors and R\&D intensity are varied in companies occupied in different industries. With reference to Hu and Png (2013), the company samples were subdivided into new and high-tech companies and non-new and high-tech companies to analyze whether the institutional investors exerted different influences on the innovation 
Tab. 4:

Robustness test

\begin{tabular}{|c|c|c|}
\hline Variable & (1) & (2) \\
\hline Institution & $\begin{array}{l}0.280^{* * *} \\
(0.065)\end{array}$ & $\begin{array}{c}0.280^{* * *} \\
(0.065)\end{array}$ \\
\hline Institution $\times$ EPUS & $\begin{array}{c}-0.051^{* * *} \\
(0.020)\end{array}$ & \\
\hline EPUS & $\begin{array}{c}0.260^{* * *} \\
(0.014)\end{array}$ & \\
\hline Institution×EPU & & $\begin{array}{c}-0.046^{* * *} \\
(0.018)\end{array}$ \\
\hline EPU & & $\begin{array}{c}0.117^{\star \star *} \\
(0.009)\end{array}$ \\
\hline $\mathrm{CCl}$ & & 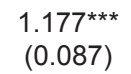 \\
\hline MLI & & $\begin{array}{c}-4.867^{* * *} \\
(0.242)\end{array}$ \\
\hline $\mathrm{ECl}$ & & $\begin{array}{c}-0.778^{* * *} \\
(0.062)\end{array}$ \\
\hline Controls variables & Yes & Yes \\
\hline Constant & $\begin{array}{c}4.118^{* * *} \\
(0.189)\end{array}$ & $\begin{array}{c}8.685^{\text {*** }}(0.311)\end{array}$ \\
\hline Year & Yes & Yes \\
\hline Industry & Yes & Yes \\
\hline Observations & 9,072 & 9,072 \\
\hline R-squared & 0.513 & 0.513 \\
\hline
\end{tabular}

Source: own

Note: ${ }^{*},{ }^{* *}$, and ${ }^{* * *}$ indicate statistical significance at the $10 \%, 5 \%$, and $1 \%$ levels, respectively; t-values reported in parentheses.

investment under aggravated economic policy uncertainty. From the regression results in columns (3) and (4) of Tab. 5, the interaction coefficient between institutional investors and economic policy uncertainty is insignificant among the new and high-tech companies but significantly negative among the non-new and high-tech companies. This result indicates that the economic policy uncertainty will aggravate the negative effect of institutional investors on the innovation investment in the non-new and high-tech companies but not on the relationship between institutional investors and innovation investment in new and high-tech companies.

Good investor protection means that the government will provide companies with advantageous policies, including talent introduction, tax preference, and fiscal subsidies (Andrlova et al., 2020). Such policies will mitigate the constraints, such as talent, tax, technology, and capital, faced by the corporate R\&D input, improve the feasibility of the R\&D input, and reduce the R\&D input risks. The investor protection index was introduced in this research, and the samples were divided into companies with strong and weak investor protection based on the median of the regional investor protection index. The regression results in columns (1) and (2) of Tab. 8 show that the interaction coefficient of innovation investment between institutional investors and economic policy uncertainty is insignificant in the area with high investor protection. However, such coefficient is significantly negative in the area with low investor protection. This result indicates that in the area with strong investor protection, the economic policy uncertainty will not result in a significant influence of institutional investors 


\section{Tab. 5: Influences of nature of property right, and industrial characteristic}

\begin{tabular}{l|c|c|c|c}
\multirow{2}{*}{\multicolumn{1}{c|}{ Variable }} & SOE & Non-SOE & High and new & No high and new \\
\cline { 2 - 5 } & $(\mathbf{1})$ & $(\mathbf{2})$ & $\mathbf{( 3 )}$ & $\mathbf{( 4 )}$ \\
\hline \multirow{2}{*}{ Institution } & $0.632^{* * *}$ & 0.075 & $0.167^{* * *}$ & $0.370^{* * *}$ \\
& $(0.130)$ & $(0.070)$ & $(0.055)$ & $(0.097)$ \\
\hline \multirow{2}{*}{ Institution×EPU } & $-0.163^{* * *}$ & 0.011 & -0.020 & $-0.067^{* *}$ \\
& $(0.039)$ & $(0.021)$ & $(0.015)$ & $(0.029)$ \\
\hline \multirow{2}{*}{ EPU } & $0.287^{* * *}$ & $0.196^{* * *}$ & $0.108^{* * *}$ & $0.240^{* * *}$ \\
& $(0.023)$ & $(0.015)$ & $(0.011)$ & $(0.016)$ \\
\hline Controls variables & Yes & Yes & Yes & Yes \\
\hline \multirow{2}{*}{ Constant } & $3.809^{* * *}$ & $4.410^{* * *}$ & $4.627^{* * *}$ & $3.213^{* * *}$ \\
& $(0.361)$ & $(0.208)$ & $(0.114)$ & $(0.201)$ \\
\hline Year & Yes & Yes & Yes & Yes \\
\hline Industry & Yes & Yes & Yes & Yes \\
\hline Observations & 3,617 & 5,455 & 4,536 & 4,536 \\
\hline R-squared & 0.524 & 0.514 & 0.726 & 0.553 \\
\hline
\end{tabular}

Source: own

Note: ${ }^{*},{ }^{* *}$, and ${ }^{* * *}$ indicate statistical significance at the $10 \%, 5 \%$, and $1 \%$ levels, respectively; t-values reported in parentheses.

on innovation investment but will significantly repress the relationship between institutional investors and innovation investment in the area with weak investor protection.
According to Doing Business Report 2020 released by the World Bank, China's ranking was elevated to 31 st place (by 15 places) in 2018. Under the innovation-driven

\section{Tab. 6: Influences of investor and IPR protection}

\begin{tabular}{l|c|c|c|c}
\multicolumn{1}{c|}{ Variable } & $\begin{array}{c}\text { High protect } \\
(\mathbf{1})\end{array}$ & $\begin{array}{c}\text { Low protect } \\
(\mathbf{2})\end{array}$ & $\begin{array}{c}\text { High IPR } \\
\mathbf{( 3 )}\end{array}$ & $\begin{array}{c}\text { Low IPR } \\
(\mathbf{4})\end{array}$ \\
\hline \multirow{2}{*}{ Institution } & $0.262^{* * *}$ & $0.290^{* * *}$ & $0.232^{* * *}$ & $0.337^{* * *}$ \\
& $(0.075)$ & $(0.080)$ & $(0.071)$ & $(0.083)$ \\
\hline \multirow{2}{*}{ Institution×EPU } & -0.032 & $-0.065^{* *}$ & -0.032 & $-0.066^{* *}$ \\
& $(0.022)$ & $(0.027)$ & $(0.021)$ & $(0.027)$ \\
\hline \multirow{2}{*}{ EPU } & $0.200^{* * *}$ & $0.246^{* * *}$ & $0.217^{* * *}$ & $0.220^{* * *}$ \\
& $(0.014)$ & $(0.016)$ & $(0.013)$ & $(0.018)$ \\
\hline Controls variables & Yes & Yes & Yes & Yes \\
\hline \multirow{2}{*}{ Constant } & $4.216^{* * *}$ & $4.086^{* * *}$ & $4.131^{* * *}$ & $4.177^{* * *}$ \\
& $(0.193)$ & $(0.203)$ & $(0.214)$ & $(0.190)$ \\
\hline Year & Yes & Yes & Yes & Yes \\
\hline Industry & Yes & Yes & Yes & Yes \\
\hline Observations & 5,004 & 4,021 & 4,931 & 4,141 \\
\hline R-squared & 0.528 & 0.510 & 0.544 & 0.483 \\
\hline
\end{tabular}

Source: own

Note: ${ }^{*},{ }^{* *}$, and ${ }^{* * *}$ indicate statistical significance at the $10 \%, 5 \%$, and $1 \%$ levels, respectively; t-values are reported in parentheses. 
development strategy, the intellectual property right (IPR) protection should be strengthened to create a good business environment (Kondić \& Knok, 2020). With powerful IPR protection, the probability for a company's innovative product and benefit to be corroded and extruded will be reduced, and the motivation for R\&D input will be enhanced (Aghion et al., 2013). After China's accession to the WTO, the country has continuously improved Patent Law and strengthened the juridical enforcement of IPR protection. With reference to Shen and Huang (2019), the regional IPR protection intensity was measured from the perspective of the regional number of settled IPR-related cases. From the regression results in columns (3) and (4) of Tab. 6, the interaction coefficient of innovation investment between institutional investors and economic policy uncertainty is insignificant in the area with a high IPR protection level. However, this coefficient is significantly negative in the area with a low IPR protection level. This result manifests that in the area with strong IPR protection, the influence of economic policy uncertainty on the institutional investors and innovation investment is weakened. However, the economic policy uncertainty evidently impedes the promoting effect of institutional investors on the innovation investment in the area with weak IPR protection.

\section{Discussion}

Through the regression results in Tab. 1, the institutional investors remarkably improve the corporate innovation investment, and this conclusion, which is identical to that of the existing literature (particularly Fan, 2018), verifies H1. The possible reason for this conclusion is that institutional investors play important roles in reducing corporate information asymmetry and relieving the principal-agent problem. With a high shareholding ratio, institutional investors can have close contact with the company management layer and acquire additional information than ordinary investors. This advantage boosts the message transmission to the external investors and reduces the information asymmetry. As proactive investors holding a great number of corporate stocks, the institutional investors fail to exit their own accord while not bearing any loss. They are motivated to take actions to supervise the companies, which will also conduct additional innovation activities. Therefore, their shareholding ratio is positively correlated with innovation investment. The increasing shareholding ratio of institutional investors will effectively discourage the company management layer from opportunistic behaviors, such as fund embezzlement (Lin et al., 2011; Lu et al., 2019b). Moreover, this increase in the shareholding ratio will lower the short-sighted decision-making pressure faced by the company management layer and increase the company resources applicable to the innovation investment.

Through the regression results in Tab. 2, after the crossover term between economic policy uncertainty and institutional investor is added, the symbol is apparently negative, which verifies $H 2$. The economic policy uncertainty weakens the promoting effect of institutional investors on innovation investment, which is a new finding of this research. The possible reason for this conclusion is that the increasing uncertainties brought by the frequent adjustment of economic policies weaken the rational market expectations made by the institutional investors (Gulen \& Ion, 2015), waver their investment resolutions, and inhibit their supporting degree for the corporate innovation investment. Moreover, the economic policy uncertainty can give rise to the fluctuation of corporate value, that is, the company may suffer from a serious decline of corporate value. Therefore, to evade the risks, the company should take conservative decisions to cope with the challenge brought by the policy fluctuations, thus reducing its innovation investment. Economic policy is an important government means of macro-regulation, and the everchanging economic policies will aggravate the uncertainty, and consequently, the investors will belittle the investment prospects. As the innovation investment is a high-risk long-term investment project, innovation investment is highly sensitive to related policies. Thus, the economic policy uncertainty weakens the promoting effect of institutional investors on the innovation investment.

From the regression results in Tab. 3, the institutional investors relieve the corporate financing constraints by improving the corporate governance and further enhance the corporate innovation investment. The advantages of institutional investments in three aspects size, personnel, and information - provide advantageous conditions for them to participate in the corporate governance, improve the internal control quality, effectively counterbalance 
the opportunistic behaviors, such as fund embezzlement of the company management layer, and increase the company resources applicable to the innovation investment (Fan, 2018). With the "wind indicator effect", the institutional investors send the positive signal of the company to the market. Then, they transmit the information that they master regarding the company's innovation activities to the capital market through their investment behaviors in way of information disclosure. This process can mitigate the information asymmetry with respect to the company's innovation activities in the capital market and help the company to attract potential external fund suppliers (Almazan et al., 2005; Guido et al., 2020). Therefore, institutional investors relieve the company's financing constraints and facilitate its innovation investment by improving corporate governance.

From the regression results in Tabs. 5 and 6, the economic policy uncertainty exerts a minor inhibitory effect on the private companies, new and high-tech companies, and those with low market competition. For the investors and companies with high IPR protection level, the institutional investors and corporate innovation investment are influenced by the economic policy uncertainty to a minimum extent. This conclusion is consistent with that of the existing literature (Ferreira \& Matos, 2008; Alan et al., 2019). Considering the diversified business objectives, the institutional investors have limited right of speech in the corporate governance of state-owned companies under the competitive manager market. The economic policy uncertainty aggravates market uncertainty. In addition, the management layer will lay more emphasis on other interests, such as political and social interests, except for economic performance when making decisions (Brown \& Petersen, 2011; Lu et al., 2019a). Therefore, conservative business strategies will be adopted, which, to a great extent, reduce the promoting effect of institutional investors on the innovation investment. If the economic policy uncertainty is high, then the risk of being knocked out is also high. The perfect and complete investor protection and IPR protection provide a system guarantee for institutional investors to participate in corporate governance. Such protection will also create a good business environment and weaken the negative impacts of economic policy uncertainty on institutional investors. Through the grouping test, the significant roles played by institutional investors in stabilizing the securities market and boosting economic development are verified.

\section{Conclusions}

The influence of institutional investors on the corporate innovation investment was explored from the perspective of economic policy uncertainty. The 2010-2018 panel data in China were used to investigate the influences of institutional investors and innovation investment. Then, the moderating effect of economic policy uncertainty on institutional investors and innovation investment was analyzed. The main conclusions are as follows: (1) Institutional investors boost the corporate innovation investment; (2) The aggravated economic policy uncertainty inhibits the promoting effect of institutional investors on the innovation investment; (3) Institutional investors improve the corporate governance and facilitate the corporate innovation investment by remitting the financing constraints; (4) The economic policy uncertainty inhibits, to a small extent, the promoting effect of institutional investors on the innovation investments of private companies, new and high-tech companies; (5) If a listed company is located in an area with a high level of investor and IPR protection, then the economic policy uncertainty has a minimal influence on the institutional investors and corporate innovation investment. The research conclusions can provide a macroscopic interpretation mechanism for developing institutional investors and reveal the importance of consistent and stable governmental economic policies to corporate development.

Enriching the related literature in the research field of innovation investment, this research provides a brand-new research idea from the perspective of institutional investors. Moreover, this study provides a useful supplementation for the innovation investment mechanism of listed companies. As an important macro factor, the economic policy uncertainty will probably become a new signal influencing the corporate innovation investment. However, limitations are not avoided in the research. For instance, the instrumental variable method cannot completely overcome the endogeneity problem. Moreover, the EPU measurement method will be disturbed by the external economic environment. Both of which, to a certain extent, give rise to some biased errors in the estimation results. 
Acknowledgments: This study was supported by the Outstanding Youth Project of Education Bureau of Hunan Province, China (20B326), the construct program of the applied characteristic discipline - Applied Economics in Hunan Province (2018469) and the General Project of Hunan Social Science Achievement Evaluation Committee (XSP21YBC193).

\section{References}

Aggarwal, R., Erel, I., Ferreira, M., \& Matos, P. (2011). Does governance travel around the world? Evidence from institutional investors. Journal of Financial Economics, 100(1), 154-181. https://doi.org/10.1016/j. jfineco.2010.10.018

Aghion, P., Reenen, J. V., \& Zingales, L. (2013). Innovation and institutional ownership. American Economic Review, 103(1), 277-304. https://doi.org/10.1257/aer.103.1.277

Agudelo, M. A. L., Jóhannsdóttir, L., \& Davídsdóttir, B. (2019). A literature review of the history and evolution of corporate social responsibility. International Journal of Corporate Social Responsibility, 4(1), 1-23. https://doi. org/10.1186/s40991-018-0039-y

Almazan, A., Hartzell, J. C., \& Starks, L. T. (2005). Active Institutional Shareholders and Costs of Monitoring: Evidence from Executive Compensation. Financial Management, 34(4), 5-34. https://doi.org/10.1111/j.1755053X.2005.tb00116.x

Amel-Zadeh, A., \& Serafeim, G. (2018). Why and How Investors Use ESG Information: Evidence from a Global Survey. Financial Analysts Journal, 74(3), 87-103. https://doi. org/10.2469/faj.v74.n3.2

An, H., \& Zhang, T. (2013). Stock price synchronicity, crash risk and institutional investors. Journal of Corporate Finance, 21(C), 1-15. https://doi.org/10.1016/j. jcorpfin.2013.01.001

Andrlova, B., \& Korytarova, J. (2020). Management of business risk hedging in construction contracts from the perspective of public investors. Technical Journal, 14(2), 168-173. https://doi.org/10.31803/tg20200515215502

Baker, S. R., Bloom, N., \& Davis, S. J. (2016). Measuring Economic Policy Uncertainty. The Quarterly Journal of Economics, 131(4), 1593-1636. https://doi.org/10.1093/qje/qjw024

Barber, B. M., \& Odean, T. (2008). All That Glitters: The Effect of Attention and News on the
Buying Behavior of Individual and Institutional Investors. The Review of Financial Studies, 21(2), 785-818. https://doi.org/10.1093/rfs/hhm079

Bhattacharya, U., Hsu, P.-H., Tian, X., \& Xu, Y. (2017). What Affects Innovation More: Policy or Policy Uncertainty? Journal of Financial and Quantitative Analysis, 52(5), 1869-1901. https://doi.org/10.1017/S0022109017000540

Bloom, N., Bond, S., \& Reenen, J. V. (2007). Uncertainty and Investment Dynamics. The Review of Economic Studies, 74(2), 391-415. https://doi.org/10.1111/j.1467937X.2007.00426.x

Boone, A. L., \& White, J. T. (2015). The effect of institutional ownership on firm transparency and information production. Journal of Financial Economics, 117(3), 508-533. https://doi. org/10.1016/j.jfineco.2015.05.008

Borochin, P., \& Yang, J. (2017). The effects of institutional investor objectives on firm valuation and governance. Journal of Financial Economics, 126(1), 171-199. https://doi. org/10.1016/j.jfineco.2017.06.013

Brown, J. R., \& Petersen, B. C. (2011). Cash holdings and R\&D smoothing. Journal of Corporate Finance, 17(3), 694-709. https://doi. org/10.1016/j.jcorpfin.2010.01.003

Bushee, B. J., \& Goodman, T. H. (2007). Which Institutional Investors Trade Based on Private Information About Earnings and Returns? Journal of Accounting Research, 45(2), 289-321. https://doi.org/10.1111/j.1475679X.2007.00234.x

Bushee, B. J., Carter, M. E., \& Gerakos, J. (2014). Institutional Investor Preferences for Corporate Governance Mechanisms. Journal of Management Accounting Research, 26(2), 123-149. https://doi.org/10.2308/jmar-50550

Callen, J. L., \& Fang, X.-H. (2013). Institutional investor stability and crash risk: Monitoring versus short-termism? Journal of Banking \& Finance, 37(8), 3047-3063. https://doi.org/10.1016/j.jbankfin.2013.02.018

Chemmanur, T. J., He, S., \& Hu, G. (2009). The role of institutional investors in seasoned equity offerings. Journal of Financial Economics, 94(3), 384-411. https://doi. org/10.1016/j.jfineco.2008.12.011

Chen, X., Harford, J., \& Li, K. (2007). Monitoring: Which institutions matter? Journal of Financial Economics, 86(2), 279-305. https://doi.org/10.1016/j.jfineco.2006.09.005

Connelly, B. L., Hoskisson, R. E., Tihanyi, L., \& Certo, S. T. (2010). Ownership as a Form of 
Corporate Governance. Journal of Management Studies, 47(8), 1561-1589. https://doi. org/10.1111/j.1467-6486.2010.00929.x

Crane, A. D., Koch, A., \& Michenaud, S. (2019). Institutional investor cliques and governance. Journal of Financial Economics, 133(1), 175-197. https://doi.org/10.1016/j. jfineco.2018.11.012

Dierksmeier, C., \& Seele, P. (2020). Blockchain and business ethics. Business Ethics: A European Review, 29(2), 348-359. https://doi.org/10.1111/beer.12259

Fan, H. F. (2018). Heterogeneous Institutional Investors, External Financing Constraints and R\&D Investment. Jinan Journal (Philosophy \& Social Science Edition), 40(11), 91-102. https://doi.org/10.3969/j.issn.10005072.2018.11.009

Ferreira, M. A., \& Matos, P. (2008). The colors of investors' money: The role of institutional investors around the world. Journal of Financial Economics, 88(3), 499-533. https://doi.org/10.1016/j.jfineco.2007.07.003

Filatotchev, I., Poulsen, A., \& Bell, R. G. (2019). Corporate governance of a multinational enterprise: Firm, industry and institutional perspectives. Journal of Corporate Finance, 57(C), 1-8. https://doi.org/10.1016/j. jcorpfin.2018.02.004

Gao, Y. Q., Wang, Y. L., Wang, L., \& Zhang, M. H. (2020). Who really cares about the environment? CEOs' military service experience and firms' investment in environmental protection. Business Ethics: A European Review, 30(1), 4-18. https://doi. org/10.1111/beer.12320

Gillan, S., \& Starks, L. T. (2003). Corporate Governance, Corporate Ownership, and the Role of Institutional Investors: A Global Perspective. Journal of Applied Finance, 13(2), 4-22. Retrieved from https://ssrn.com/ abstract $=480983$

Gu, Y. W., Filatotchev, I., Bell, R. G., \& Rasheed, A. R. (2019). Liability of foreignness in capital markets: Institutional distance and the cost of debt. Journal of Corporate Finance, 57(C), 142-160. https://doi.org/10.1016/j. jcorpfin.2017.10.014

Guido, G., Amatulli, C., \& Sestino, A. (2020). Elderly consumers and financial choices: A systematic review. Journal of Financial Services Marketing, 25(4), 76-85. https://doi. org/10.1057/s41264-020-00077-7
Gulen, H., \& Ion, M. (2016). Policy Uncertainty and Corporate Investment. The Review of Financial Studies, 29(3), 523-564. https://doi.org/10.1093/rfs/hhv050

Hadlock, C. J., \& Pierce, J. R. (2010). New Evidence on Measuring Financial Constraints: Moving Beyond the KZ Index. The Review of Financial Studies, 23(5), 1909-1940. https://doi.org/10.1093/rfs/hhq009

Hartzell, J. C., \& Starks, L. T. (2003). Institutional Investors and Executive Compensation. Journal of Finance, 58(6), 2351-2374. https://doi.org/10.1046/j.15406261.2003.00608.x

Hu, A. G. Z., \& Png, I. P. L. (2013). Patent rights and economic growth: Evidence from cross-country panels of manufacturing industries. Oxford Economic Papers, 65(3), 675-698. https://doi.org/10.1093/oep/gpt011

Hoque, M. E., Kabir Hassan, M., Hashim, N. M. H. N., \& Zaher, T. (2019). Factors affecting Islamic banking behavioral intention: the moderating effects of customer marketing practices and financial considerations. Journal of Financial Services Marketing, 24(5), 44-58. https://doi.org/10.1057/s41264-019-00060-x

Jahnke, P. (2019). Ownership concentration and institutional investors' governance through voice and exit. Business and Politics, 21(3), 327-350. https://doi.org/10.1017/bap.2019.2

Ju, X. S., Lu, D., \& Yu, Y. H. (2013). Financing constraints, working capital management and the persistence of firm innovation. Economic Research Journal, 1, 4-16.

Kondić, Ž., \& Knok, Ž. (2020). Risk Management in the Higher Education Quality Insurance System. Technical Journal, 14(1), 4654. https://doi.org/10.31803/tg-20200310141424

Kong, D. M., Liu, S. S., \& Tan, W. Q. (2019). Analyst recommendations and different investors' trading. Management World, 1, 167-178. https://doi.org/10.19744/j.cnki.111235/f.2019.0012

La Porta, R., Lopez-de-Silanes, F., Shleifer, A., \& Vishny, R. (2000). Investor protection and corporate governance. Journal of Financial Economics, 58(1-2), 3-27. https://doi. org/10.1016/S0304-405X(00)00065-9

Li, L., \& Han, L. Y. (2014). Value investing or value creating? A comparative study between foreign and domestic institutional investors. China Economic (Quarterly), 1, 351-372. https://doi.org/10.13821/j.cnki.ceq.2014.01.014 
Li, W. A., \& Li, B. (2008). An Empirical Study on the Effect of Institutional Investors Participating in Corporate Governance: Based on the Data of 2004-2006 CCGI (NK). Nankai Business Review, 1, 4-14.

Liang, S. K. (2018). Will institutional investor ownership affect companies' stickiness of cost? Management World, 12, 133-148. https://doi. org/10.19744/j.cnki.11-1235/f.2018.0039

Lin, C., Yue, M., \& Xuan, Y. H. (2011). Ownership structure and financial constraints: Evidence from a structural estimation. Journal of Financial Economics, 102(2), 416-431. https://doi.org/10.1016/j.jfineco.2011.06.001

Lu, J. T., Ren, L. C., He, Y. F., Lin, W. F., \& Streimikis, J. (2019a). Linking corporate social responsibility with reputation and brand of the firm. Amfiteatru Economic, 21(51), 442-460. https://doi.org/10.24818/EA/2019/51/442

Lu, J. T., Ren, L. C., He, Y. F., Lin, W. F., \& Streimikis, J. (2019b). Policies to Promote Corporate Social Responsibility (CSR) and Assessment of CSR Impacts. E\&M Economics and Management, 22(1), 82-98. https://doi. org/10.15240/tul/001/2019-1-006

Lu, J. T., Ren, L. C., Qiao, J. Y., Lin, W. F., \& He, Y. F. (2019c). Female Executives and Corporate Social Responsibility Performance: A Dual Perspective of Differences in Institutional Environment and Heterogeneity of Foreign Experience. Transformations in Business \& Economics, 18(2), 174-196.

Lu, Y., Zhu, Y. J., \& Hu, X. Y. (2012). Institutional Shareholding and Corporate Fraud: Evidence from China. Nankai Business Review, 15(1), 13-23. https://doi.org/10.3969/j. issn.1008-3448.2012.01.003

McCahery, J. A., Sautner, Z., \& Starks, L. T. (2016). Behind the Scenes: The Corporate Governance Preferences of Institutional Investors. Journal of Finance, 71(6), 2905-2932. https://doi.org/10.1111/jofi.12393

Nofsinger, J. R., Sulaeman, J., \& Varma, A. (2019). Institutional investors and corporate social responsibility. Journal of Corporate Finance, 58, 700-725. https://doi.org/10.1016/j. jcorpfin.2019.07.012

Pan, X., Chen, X. J., Guo, H. J., \& Zhang, Y. C. (2020). One size doesn't fit all: How institutional complexity within the state shapes firms' environmental innovation. Business Ethics: A European Review, 29(3), 438-450. https://doi.org/10.1111/beer.12280
Panousi, V., \& Papanikolaou, D. (2012). Investment, Idiosyncratic Risk, and Ownership. The Journal of Finance, 67(3), 1113-1148. https://doi.org/10.1111/j.15406261.2012.01743.x

Pástor, L., \& Veronesi, P. (2013). Political uncertainty and risk premia. Journal of Financial Economics, 110(3), 520-545. https://doi.org/10.1016/j.jfineco.2013.08.007

Rao, P. G., Yue, H., \& Jiang, G. H. (2017). Economic policy uncertainty and firms' investment. The Journal of World Economy, 2, 27-51.

Schmalz, M. C. (2018). Common-ownership Concentration and Corporate Conduct. Annual Review of Financial Economics, 10, 413-448. https://doi.org/10.1146/annurevfinancial-110217-022747

Shen, G. B., \& Huang, S. J. (2019). The impact of city-level intellectual property protection on foreign capital entry into Chinese enterprises. Finance \& Trade Economics, 12, 143-157. https://doi.org/10.19795/j.cnki.cn111166/f.20191204.003

Wen, Z. L., Chang, L., \& Hou, J. T. (2006). Mediated Moderator and Moderated Mediator. Acta Psychologica Sinica, 38(3), 448-452. http://journal.psych.ac.cn/acps/EN/Y2006/V38/ 103/448

Whited, T. M., \& Wu, G. J. (2006). Financial Constraints Risk. The Review of Financial Studies, 19(2), 531-559. https://doi. org/10.1093/rfs/hhj012

Wondirad, H. A. (2020). Competition and microfinance institutions' performance: evidence from India. International Journal of Corporate Social Responsibility, 5(1), 1-19. https://doi.org/10.1186/s40991-020-00047-1

Xie, W. M., \& Fang, H. X. (2011). Financial development, financing constrains and firms' R\&D investment. Journal of Financial Research, 5, 171-183.

Xu, N., Zhang, Y., \& Xu, X. Y. (2019). Can managerial ability protect the interests of minority shareholders in subsidiaries: A perspective of parent-subsidiary's "Two-way Governance". China Industrial Economics, 11, 155-173. https://doi.org/10.19581/j.cnki. ciejournal.2019.11.009

Yi, Z. H., Jiang, F. X., \& Qin, Y. H. (2010). The market competition in products, the corporate governance and the quality of information disclosure. Management World, 1, 133-141. https://doi.org/10.19744/j.cnki.111235/f.2010.01.015 